\title{
Континентальность климата Сибирского региона
}

\author{
С.Н. Соколов ${ }^{凶}$, Э. А. Кузнецова \\ Нижневартовский государственныий университет, Российская Федераиия \\ (628602, г. Нижневартовск, ул. Ленина, 56)
}

\begin{abstract}
Аннотация: Цель исследования - провести анализ существующих показателей континентальности климата для территории Сибири. Изучение континентальности климата является актуальной задачей, так как континентальность накладывает ограничения на освоение территории.

Memoдbl. Существует множество показателей, позволяющих оценить континентальность климата количественно, но именно их многочисленность показывает, ни один из них не может считаться универсальным. Для оценки климатических условий предлагается использовать коэффициент общей годовой континентальности, учитывающий среднюю январскую и среднюю июльскую температуру, сумму зимних и сумму летних осадков, а также широту местности.

Результаты. Построена карта распределения предложенного коэффициента, анализ которой показывает сложную картину изменения континентальности в пространстве. Он позволяет выделить 6 зон, которые протянулись с северо-запада на юго-восток Сибири. Наименьшие показатели коэффициента наблюдаются на большей части Западной Сибири и запада Красноярского края. Максимальные величины характерны для горных районов Тывы и Алтая, а также для южной части Забайкальского края. Полученные результаты свидетельствуют, что климатические условия наименее благоприятны на севере и востоке Сибири, на западе же являются относительно комфортными по сравнению с другими регионами.

Заключение. Климатические условия имеют особую значимость в Сибири, так как континентальность климата мало изучена, существуют лишь обобщённые данные, характеризующие территорию в целом. Индексы, полученные по разным методикам расчета, показывают увеличение континентальности климата с северо-запада на юго-восток. Для полной оценки географического положения региона следует учитывать «отрицательный потенциал» освоения его ресурсов, оценка которого должна начинаться с климата.
\end{abstract}

Ключевые слова: климат, континентальность, коэффициенты континентальности, коэффициент общей годовой континентальности, Сибирь.

Для цитирования: Соколов С. Н., Кузнецова Э. А. Континентальность климата Сибирского региона // Вестник Воронежского государственного университета. Серия География. Геоэкология, 2020, № 4, c. 44-52. DOI: https://doi.org/10.17308/geo.2020.4/3064

\section{ВВЕДЕНИЕ}

Северность географического положения Сибири накладывает жесткие ограничения не только на возможности региональной экономики, но и освоения территории вообще [18]. Так, например, строительство и поддержание в надлежащем порядке дорожно-транспортной сети, разрушаемой поверхностными и грунтовыми водами, укрепление инженерных сооружений из-за обильных снегопадов, обледенением и деформациями металла, вызываемыми перепадом температур, требуют дополни-

(C) Соколов С.Н., Кузнецова Э.А., 2020

๑ Соколов Сергей Николаевич, e-mail: snsokolov1@yandex.ru тельных средств [10]. Немалые убытки связаны с ликвидацией последствий ледостава и ледохода, паводковых наводнений [11]. По сути, территория севера Сибири является зоной рискованного хозяйства для всех отраслей производства [22]. Треть местного населения испытывает дополнительные трудности, находясь в экстремальных климатических условиях [12].

Ресурсы климата используются в различных отраслях производственной и непроизводственной сфер. В этой ситуации географическая оценка климатических условий жизни людей и хозяйствен-

Контент доступен под лицензией Creative Commons Attribution 4.0 License. 
ного освоения приобретает особую актуальность [20]. Тема важна, актуальна, интересна как для экономики, так и проживающего здесь населения, а также имеет научно-практическую значимость. Для полной оценки географического положения региона следует учитывать потенциал освоения его ресурсов, оценка которого должна начинаться с климата [21].

\section{МЕТОДИКА ЭКСПЕРИМЕНТА}

На качество среды обитания влияет множество климатических факторов, для учета которых разработан широкий набор различных показателей, из которых обычно на практике выбирается несколько ведущих, используемых в качестве критериев для климатической оценки. Одним из показателей климата, который, по мнению А.Г. Исаченко [8], является интегральной характеристикой климатического режима ландшафтов, является степень его континентальности.

Существует множество формул, позволяющих оценить континентальность климата количественно, но именно их многочисленность показывает, что ни один из них не может считаться безупречным. В 1884 году А. Супан впервые использовал годовую амплитуду температур при вычислении индекса континентальности. На климат влияют большие просторы суши или океанов [33]. Если рассматривать характеристики, то можно утверждать, что континентальному климату свойственны по сравнению с морским более высокие годовые и суточные амплитуды температур, меньшее количество осадков [31]. Степень континентальности климата считается важной интегральной характеристикой климатического режима ландшафтов. Океаничность и континентальность являются важными понятиями в изучении климата [35]. Под континентальностью климата понимается совокупность воздействия материка на многие элементы, характеризующие ход метеорологических процессов. В качестве меры континентальности обычно используют годовую амплитуду температур [3], но также существует понятие орографической континентальности. Она может наблюдаться как во внутренних районах материков, так и вблизи побережий и характеризует региональные орографические особенности территорий [4].

В низких широтах годовые амплитуды температуры меньше, чем в высоких широтах, даже в континентальных условиях, поэтому для определения показателей континентальности обязательно используют поправку на географическое поло- жение, выраженную через широту местности [19, 30]. Соотношением между годовой амплитудой температур и географической широтой определяют индекс континентальности. Формула Горчинского является наиболее часто применяемой во многих исследованиях [3, 6, 13, 23, 27, 32, 34, 37]. Некоторые исследователи включают не только температуру, но и осадки в климатические индексы $[28,36]$.

Существует достаточно много методов определения степени континентальности климата. К показателям континентальности климата относятся следующие.

1. Коэффициент континентальности Ценкеpa [16]:

$$
K_{z}=\frac{600 A}{5 \varphi}-20
$$

2. Коэффициент континентальности Шрепфера [16]:

$$
K_{S c h}=\frac{800 A}{7 \varphi}-14
$$

3. Коэффициент континентальности В. Конрада [30]:

$$
K_{C}=\frac{1,7 A}{\sin (\varphi+10)}-14
$$

4. Коэффициент континентальности Л. Горчинского $[9,16]$ :

$$
K_{G}=\frac{1,7 A}{\sin \varphi}-20,4
$$

5. Коэффициент континентальности С.П. Хромова [24]:

$$
K_{K h}=\frac{A-5,4 \sin \varphi}{A}
$$

6. Коэффициент континентальности Н.Н. Иванова [7, 16]:

$$
K_{I}=\frac{A}{0,33 \varphi}
$$

7. Коэффициент континентальности А. Эверта [38]:

$$
K_{E}=\frac{A-(3,81 \sin \varphi+0,1)}{38,39 \sin \varphi+7,47} \times 100
$$

8. Коэффициент континентальности Джонассона-Ринглеба [29]:

$$
K_{J R}=0,6\left(1,6 \frac{A}{\sin \varphi}-14\right)-\left(T_{I X-X I}-T_{I I I-V}\right)+36(8)
$$


В приведенных формулах (1-8) приняты следующие обозначения:

$A$ - годовая амплитуда температур $\left({ }^{\circ} \mathrm{C}\right), \varphi$ - широта местности ( ${ }^{\circ}$ с.ш.); $T_{I X-X I}-$ средняя температура осени (сентябрь - ноябрь), $T_{I I I-V}-$ средняя температура весны (март - май).

Минимальные значения индексов континентальности соответствуют морскому климату, максимальные - континентальному климату [14]. Все предложенные выше коэффициенты континентальности, рассчитанные по формулам (1-8), учитывают только два показателя - широту местности и температуру воздуха. Тем не менее, известно, что чем меньше количество осадков, то климат более континентальный [12]. Конечно же, распределение осадков не является определяющим признаком континентальности климата, но, желательно, учитывать и этот показатель.

Региональный индекс континентальности был предложен Н.Ф. Харламовой, который представляет модификацию индекса Хромова с учетом влагообеспеченности, как важнейшего фактора функционирования ландшафтов внутриконтинентальной территории [23]:

$$
K_{R}=\frac{A-5,4 \sin \varphi}{A} \cdot \frac{R_{I V-X}}{100} \cdot 100 \%,
$$

где $R_{I V-X}-$ среднемноголетняя сумма осадков теплого периода (апрель-октябрь).

Кроме того существует коэффициент континентальности климата Ц. А. Швер [26]:

$$
K_{S h}=\frac{\sum R_{I I I-V I I I}}{\sum R_{X-I I I}}
$$

где $\sum R_{I I I-V I I I}$ - сумма осадков в весенне-летний период (мм), $\sum R_{X-I I I}$ - сумма осадков в осеннезимний период (мм).

Коэффициент континентальности климата, рассчитанный по данной методике учитывает только сумму осадков, но не использует ни широту местности, ни температуру воздуха.

Авторы считают, что нужно принять такой показатель континентальности, чтобы по мере приближения к океану он уменьшался, стремясь к нулю. Поэтому предлагается коэффициент зимней континентальности [17]:

$$
K_{w}=\left(\left(1-T_{w} / t_{0}\right) \cos \varphi+P_{0} / P_{w}-2\right) / 2,
$$

где $T_{w}$ - средняя январская температура, $t_{0}-$ средняя годовая температура на уровне океана на широте умеренного пояса (приблизительно равная $\left.+8^{\circ} \mathrm{C}[21]\right), \varphi-$ широта местности ( ${ }^{\circ}$ с.ш. $), P_{0}-$ сумма осадков за год в открытом океане на широтах умеренного пояса (примерно равная 1000 мм); $P_{w}-$ сумма осадков с октября по март (включительно).

Можно выявить территории в Сибири, где максимальные различия между континентом и океаном приходится на лето, поэтому при анализе континентальности необходимо рассчитывать коэффициент летней континентальности, для чего предлагается следующая формула [17]:

$$
K_{s}=\left(\left(T_{s} / t_{0}-1\right) \sin \varphi+P_{0} / P_{s}-2\right) / 2,
$$

где $T_{s}$ - средняя июльская температура, $t_{0}-$ средняя годовая температура на уровне океана на широте умеренного пояса (приблизительно равная $\left.+8^{\circ} \mathrm{C}\right), \varphi$ - широта местности ( ${ }^{\circ}$ с.ш.), $P_{0}$ - сумма осадков за год в открытом океане на широтах умеренного пояса (примерно равная 1000 мм), $P_{s}$ - сумма осадков с апреля по сентябрь (включительно).

Таким образом, коэффициент общей годовой континентальности климата будет вычисляться по формуле:

$$
\begin{gathered}
K_{t}=K_{w}+K_{s} \\
\text { ОБСУЖДЕНИЕ РЕЗУЛЬТАТОВ }
\end{gathered}
$$

Информационной базой для оценки климата служили данные материалов наблюдений на метеорологических станциях Сибири. В результате проведенных расчетов была составлена база данных. По полученным показателям можно сравнить отдельные города Сибири в относительных величинах - коэффициентах континентальности климата.

Анализируя расчетные данные, можно заметить, что показатели дают различную величину степени континентальности, что объясняется индивидуальностью подхода к ее оценке. Нетрудно определить, что индексы, полученные по разным методикам расчета, показывают увеличение континентальности климата с северо-запада на юго-восток.

Степень континентальности по коэффициенту Л. Горчинского увеличивается на территории Сибири с запада на восток и с севера на юг. Минимальные значения в Сибири на мысе Челюскин $(33,7)$, что соответствует умеренно континентальному климату, максимальные в поселке УстьMae $(96,7)$, т.е. здесь самый континентальный климат. Коэффициент континентальности климата С. П. Хромова на территории Сибири изменяется в пределах от 83,0 (мыс Челюскин) до 92,2 (пос. Усть-Мая). Значения коэффициента континентальности Н.Н. Иванова изменяются от 1,2 (мыс Челюскин) до 3,1 (пос. Усть-Мая). Благода- 


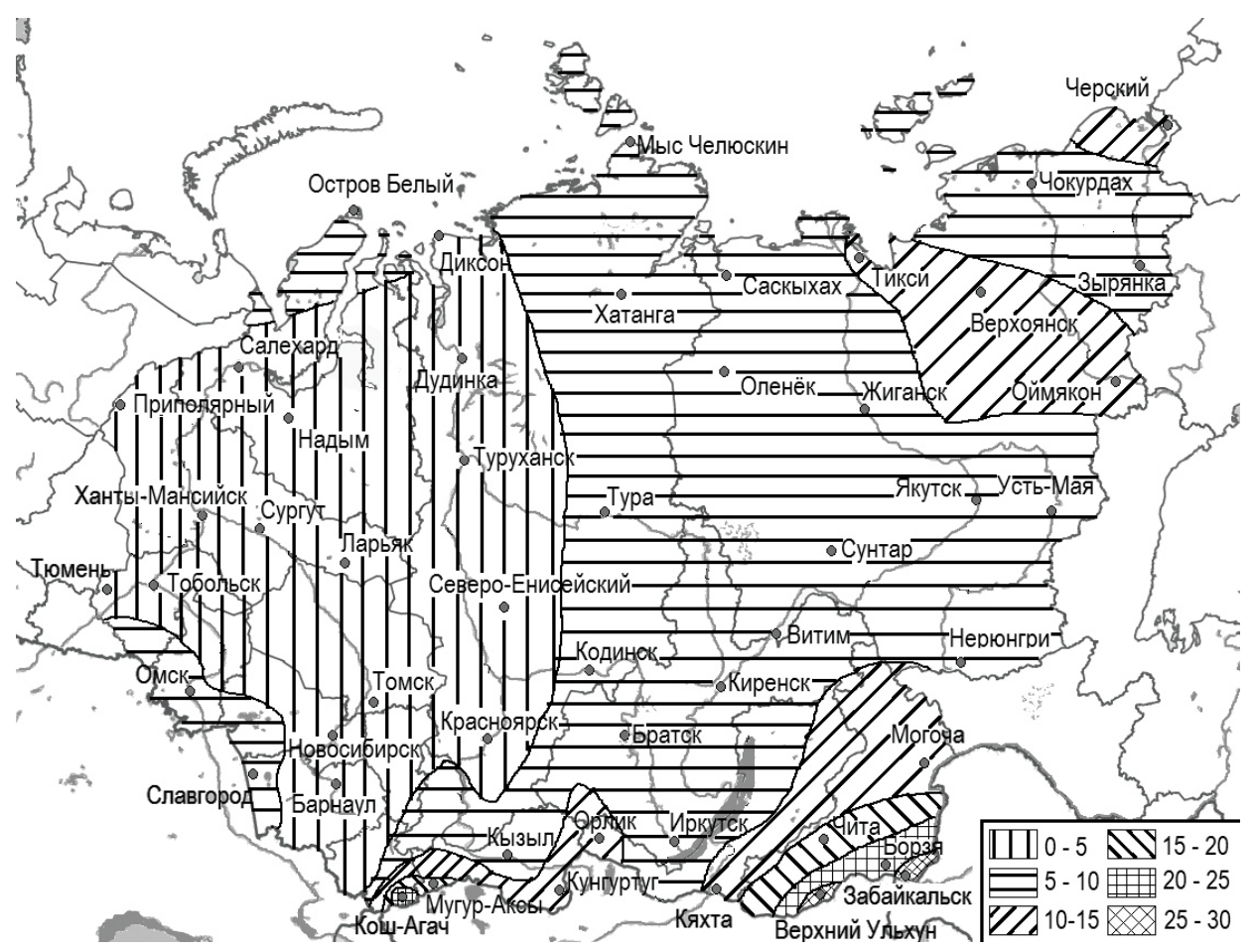

$P u c$. Значение коэффициента общей годовой континентальности

[Fig. The value of the coefficient of the total annual continentality]

ря отепляющему влиянию Братского водохранилища и озера Байкал, в городах, расположенных на их берегах, величина рассматриваемого показателя выделяется на общем фоне [11].

Коэффициент общей годовой континентальности минимален в поселках Приполярный $(2,7)$ и Северо-Енисейский $(2,9)$. Максимальные значения характерны для поселков Забайкальск $(27,9)$ и Верхний Ульхун $(28,5)$ в Забайкальском крае.

В результате проведенных расчетов нами была построена карта коэффициента общей годовой континентальности (рис.).

Анализ карты распределения данного коэффициента показывает сложную картину изменения континентальности в пространстве. Так, например, он позволяет выделить 6 зон, которые протянулись с северо-запада на юго-восток Сибири. Наименьшие показатели коэффициента общей годовой континентальности (0-5) наблюдаются на большей части Западной Сибири и запада Красноярского края. Вторая и третья зоны (5-15) располагаются на северо-западе полуострова Ямал, юго-западе Западной Сибири, гор Южной Сибири, Саха (Якутии) и востоке Красноярского края. Максимальные величины (25-30) характерны для горных районов Тывы и Алтая, а также для южной части Забайкальского края.

Континентальность климата влияет на экологические системы и социальные условия, от кото- рых зависят урожайность, водоснабжение, модели развития инфекционных заболеваний, меры реагирования и готовности к бедствиям, социальные потрясения, миграционные процессы и конфликтные ситуации в обществе. Одна из задач изучения климатических особенностей территории состоит в том, чтобы на базе метеорологической информации оценить возможное влияние климата на организм человека [1]. Изменение климата представляют серьезную опасность для здоровья населения Сибири, стимулирует развитие и других экологических рисков, таких как: засуху, наводнения, аномально высокие температуры воздуха, снижение производительности сельского хозяйства, экологически зависимые и паразитарные заболевания среди населения $[15,25]$. На территории России в последние десятилетия потепление климата происходило быстрее и масштабнее, чем на остальной части Земного шара [2]. Глобальное изменение климата для России диктует необходимость заблаговременного формирования всеобъемлющего и взвешенного подхода государства к проблемам климата [5].

В этой ситуации географическая оценка климатических условий жизни людей и хозяйственного освоения приобретает особую актуальность. Климатические условия наиболее неблагоприятны на севере и востоке Сибири, а на западе явля- 
ются относительно комфортными по сравнению с другими регионами Сибири.

\section{ЗАКЛЮЧЕНИЕ}

Таким образом, при оценке континентальности климата Сибирского региона нами было выявлено следующее.

1. Климатические условия имеют особую значимость в Сибири, тем более что рассматриваемая проблема мало изучена, существуют лишь обобщённые данные, характеризующие территорию в целом, без детального рассмотрения отдельных регионов.

2. Индексы, полученные по разным методикам расчета, показывают увеличение континентальности климата с северо-запада на юго-восток.

3. Для полной оценки географического положения региона следует учитывать «отрицательный потенциал» освоения его ресурсов, оценка которого должна начинаться с климата.

4. Тема важна, актуальна и интересна как для региональной экономики, так и проживающего здесь населения, а также имеет научно-практическую значимость. Континентальность климата накладывает ограничения не только на возможности экономики, но и освоения территории вообще.

\section{СПИСОК ЛИТЕРАТУРЫ}

1. Акимов Л. М. Анализ жесткости климатических условий Белгородской области в зимний период // Becтник Воронежского государственного университета. Серия География. Геоэкология, 2012, № 2, с. 76-80.

2. Акимов Л. М., Задорожная Т. Н., Закусилов В.П. Климатическая неоднородность температуры воздуха на территории Восточной Европы в весенний период // Вестник Воронежского государственного университета. Серия География. Геоэкология, 2019, № 1, с. 29-38. DOI: https://doi.org/10.17308/geo.2019.1/2283.

3. Андрейчик М.Ф., Монгуш Л.Д.-Н. Исследование индекса континентальности на фоне потепления климата в Хемчикской котловине Республики Тыва // Вестник КрасГАУ, 2013, № 7, с. 146-151.

4. Барышникова О.Н., Крупочкин Е.П., Мезенцева Е. М., Неприятель Р. С., Харламова Н.Ф. Континентальность и океаничность как факторы формирования ландшафтной структуры территории // Известия Алтайского государственного университета, 2010, № 31(67), с. 89-92.

5. Бедрицкий А. И., Куролап С. А., Вильфанд Р. М., Дмитриева В.А. Стратегические направления обеспечения экологической и гидрометеорологической безопасности России в условиях современных климатических изменений // Вестник Воронежского государственного университета. Серия География. Геоэкология,
2019, № 4, c. 5-14. DOI: https://doi.org/10.17308/ geo.2019.4/2706

6. Бойченко С. Г., Волощук В. М., Сердюченко Н. Н. Современные пространственно-временные вариации индекса континентальности и амплитуды сезонного хода приземной температуры на территории Украины // Доповіді Наџіональної академії наук України, 2017, № 9, c. 67-75. DOI: https://doi.org/10.15407/dopovidi2017.09.067/

7. Иванов Н.Н. Пояса континентальности земного шара // Известия Всесоюзного Географического общчества, 1959, т. 91, вып. 5, с. 410-423.

8. Исаченко А. Г. Экологическая география России. СПб., Изд-во С.-Петерб. ун-та, 2001. 328 с.

9. Киреева-Гененко И. А., Новикова Е. П., Чумейкина А.С. Анализ и оценка индекса континентальности климата в Центрально-Черноземном районе за последние 30 лет // Успехи современного естествознания, 2017, № 7, c.76-80.

10. Кузнецова Э.А. Изучение континентальности климата территории Сибири // Современные проблемы географии и геологии: к 100-летию открытия естественного отделения в Томском государственном университете: Матер. IV Всерос. науч.-практ. конф. Т. 1. Томск, Томский гос. ун-т, 2017, с. 287-289.

11. Кузнецова Э. А. Функции экосистем в зоне инженерного освоения // Экологическое равновесие: природное и историко-культурное наследие, его сохранение и популяризация: Матер. VI междунар. науч.практ. конф. СПб., Лен. гос. ун-т им А.С. Пушкина, 2015, c. 133-136.

12. Кузнецова Э. А., Соколов С.Н. Гидрология, метеорология и климатология: климатические расчеты: учебное пособие. Нижневартовск, НВГУ, 2019. 86 с.

13. Лапина С.Н. Характеристика континентальности климата Саратова и Санкт-Петербурга на фоне глобального потепления // Известия Саратовского университета. Нов. сер. Серия Науки о Земле, 2017, т. 17, вып. 4, c. 219-221. DOI: 10.18500/1819-7663-2017-17-4-219-221.

14. Михайлов В. А. Анализ континентальности климата Крымского полуострова с помощью ГИС // Проблеми безперервної географічної освіти і картографії: Збірник наукових працьь. Харків, 2014, вип. 19, с. 72-76.

15. Погонышева И.А., Кузнецова В.П., Погонышев Д. А., Луняк И. И. Европейские исследования в рамках влияния изменения климата на здоровье человека и окружающую среду // Окружающая среда и здоровье человека: опыт стран Евросоюза: Материаль научно-практического семинара. Нижневартовск, ИЦ «Наука и практика», 2018, с. 26-32. DOI: http://doi.org/ 10.5281/zenodo.1165006.

16. Пряхина С.И., Ормели Е.И. Расчет индексов континентальности климата для Среднего и Нижнего Поволжья // Известия Саратовского университета. Нов. сер. Серия Науки о Земле, 2017, т. 17, вып. 1, с. 1719. DOI: 10.18500/1819-7663-2017-17-1-17-19.

17. Соколов С.Н. Пространственно-временная организация производительных сил Азиатской России. 
Нижневартовск, Изд-во Нижневартовск. гос. гуманит. ун-та, 2006. 317 с.

18. Соколов С.Н. Современное экономико-географическое положение Югры // География и регион: Матер. Междунар. науч.-практ. конф. Пермь, Перм. гос. нац. иссл. ун-т, 2015, Т.III, с. 167-173.

19. Соколов С.Н. Теоретико-методологические и методические основы диагностики проблем социально-экономического развития регионов Азиатской России. Новосибирск, ООО агентство «Сибпринт», 2013. $205 \mathrm{c}$.

20. Соколов С. Н. Экономико-географическое положение Нижневартовского региона // Вестник Нижневартовского гос. университета, 2012, № 1, с. 21-31.

21. Соколов С.Н., Кузнецова Э. А. Оценка условий жизни населения ХМАО - Югры по биоклиматическим индексам // Глобальные климатические изменения: региональные эффекты, модели, прогнозы: Матер. Междунар. науч.-практ. конф. Воронеж, Изд-во «Цифровая полиграфия», 2019, т. 2, с. 390-394.

22. Соколов С.Н., Ржепка Э. А. Проблемы и перспективы развития производительных сил регионов Азиатской России // Природа и общество: в поисках гармонии, 2018, № 4, с. 110-120.

23. Харламова Н.Ф. Оценка и прогноз современных изменений климата Алтайского региона. Барнаул: Издво Алтай. гос. ун-та, 2013. 156 с.

24. Хромов С.П. Метеорология и климатология: развитие науки, географические факторы климата. Тепловой режим атмосферы. Индексы континентальности. Ленинград, Гидрометеоиздат, 1978. 345 с.

25. Чиглинцев В.М., Кузнецова Э.А., Коломоец В. В. Влияние климатогеографических условий проживания населения XМАО - Югры на здоровье молодого поколения // Межкультурный диалог и сотрудничество ЕС и России: опыт реализации проектов Жан Монне в Нижневартовском государственном университете: Матер. междунар. науч.-практ. конф. Нижневартовск, Нижневарт. гос. ун-т, 2019. с. 103-108.

26. Швер Ц. А. Атмосферные осадки на территории СССР. Ленинград, Гидрометеоиздат, 1976. 302 с.

27. Baltas E. A. Climatic Conditions and Availability of Water Resources in Greece // International Journal of
Water Resources Development, 2008, v. 24, no. 4, pp. 635649.

28. Charles-Edwards D. A. Physiological determination of crop growth. Sydney, Academic Press, 1984. 161 p.

29. Ciaranek D. Variability of the thermal continentality index in Central Europe // Aerul si Apa: Componente ale Mediului, v. 63. pp. 307-313.

30. Conrad V., Pollak L. W. Methods in climatology. 2nd edition. Cambridge, Harvard university press, 1950. 459 p.

31. Deniz A., Toros H., Incecik S. Spatial variations of climate indices in Turkey // International Journal of Climatology, 2011, v. 41. пою 3, pp. 394-403.

32. Filatov N., Salo Y., Nazarova L. Effect of climate variability on natural water bodies in Northwest Russia // Proc. 15th Northern Research Basins Symposium. Lulea to Kvikkjokk, Sweden, 2005, pp. 31-40.

33. Gadiwala M.S., Burke F., Alam M. T., Nawaz-ulHuda S., Azam M. Oceanity and continentality climate indices in Pakistan // Geografia - Malaysian Journal of Society and Space, 2013, v. 9, no. 4, pp. 57-66.

34. Gavilan R. G. The use of climatic parameters and indices in vegetation distribution. A case study in the Spanish System Central // International Journal of Biometeorology, 2005, no. 50, pp. 111-120.

35. Rajabi A., Shabanlou S. Index changes in future by using SDSM in Kermanshah Iran // J. Environ. Res. Develop, 2012, v. 7, no. 1, pp. 37-44.

36. Rosenberg N.J., Blad B.L., Verma S.B. Microclimate: The biological environment. 2nd edition. New York, Wiley, 1983. 495 p.

37. Sjogersten S., Wookey P.A. Decomposition of mountain birch leaf litter at the forest-tundra ecotone in the Fennoscandian Mountains in relation to climate and soil conditions // Plant and Soil, 2004, v. 262, pp. 215-227.

38. Szymanowski M., Bednarczyk P., Kryza M., Nowosad M. Spatial Interpolation of Ewert's Index of Continentality in Poland // Pure Appl. Geophys, 2017, v. 174, pp. 623-642.

Конфликт интересов: Авторы декларируют отсутствие явных и потенциальных конфликтов интересов, связанных с публикацией настоящей статьи.

Поступила в редакцию 14.01.2020 Принята к публикаџии 20.11.2020 


\title{
Continentality of climate in Siberian region
}

\author{
S. N. Sokolov ${ }^{\bowtie}$, E. A. Kuznetsova \\ Nizhnevartovsk State University, Russian Federation \\ (56, Lenin st., Nizhnevartovsk, 628602)
}

\begin{abstract}
The purpose of the study is to analyze existing indicators of climate continentality in the Siberian region. The study of climate continentality is a relevant objective because continentality imposes restrictions on territorial development. Methods. There are many indicators for quantification of climate continentality however within a great multiplicity of those methods there is none that is impeccable and versatile. It is therefore proposed to use a coefficient of a total annual continentality by taking into account average January and July temperatures, winter and summer precipitation and latitude of area to estimate climatic conditions.

Results. The chart of distribution of proposed coefficient was developed and analyzed. It shows a complex picture of continentality changes in space. Analysis highlights 6 zones that extend from the northwest to the southeast of Siberia. The lowest coefficient is the case for the most of Western Siberia and the west of Krasnoyarsk territory. The maximum values are characteristic of mountainous regions of Tuva Republic and Altai, southern part of Zabaykalsky Krai. The results showed that climatic conditions are most adverse in the north and east of Siberia. The west is characterized by relatively comfortable climatic conditions compared to other regions.

Conclusion. Climatic conditions are particularly relevant in Siberia. Since continental climate is underresearched, existing are rather general and normally characterize the area as a whole. Indices obtained by different methods of calculating show increase in climate continentality from the northwest to the southeast. The "negative potential" of resource development should be taken into account to fully assess geographical location of the region and its assessment should begin with the climate.
\end{abstract}

Key words: climate, continentality, coefficient of continentality, coefficient of a total annual continentality, Siberia.

For citation: Sokolov S. N., Kuznetsova E. A. Continentality of climate in Siberian region. Vestnik Voronezskogo gosudarstvennogo universiteta. Seria Geografia. Geoekologia, 2020, No. 4, pp. 44-52. (In Russ.) DOI: https://doi.org/10.17308/geo.2020.4/3064

\section{REFERENCES}

1. Akimov L. M. Analiz zhestkosti klimaticheskikh usloviy Belgorodskoy ooblasti $\mathrm{v}$ zimniy period [Analysis of rigorous climatic conditions of the Belgorod region in winter]. Vestnik Voronezskogo gosudarstvennogo universiteta. Seria Geografia. Geoekologia, 2012, no. 2, pp. 76-80. (In Russ.)

2. Akimov L. M., Zadorozhnaya T. N., Zakusilov V.P. Klimaticheskaya neodnorodnost temperatury vozdukha na territorii Vostochnoy Evropy v vesenniy period [The climatic heterogeneity of air temperature in eastern europe in spring period]. Vestnik Voronezskogo gosudarstvennogo universiteta. Seria Geografia. Geoekologia, 2019, no. 1, pp. 29-38. DOI: https://doi.org/10.17308/geo.2019.1/2283. (In Russ.)

(C) Sokolov S. N., Kuznetsova E. A., 2020

\. Sergey N. Sokolov, e-mail: snsokolov1@yandex.ru
3. Andreychik M.F., Mongush L.D.-N. Issledovanie indeksa kontinentalnosti na fone potepleniya klimata $\mathrm{v}$ Khemchikskoy kotlovine Respubliki Tyva [The continentality index research on the climate warming background in Khemchikskaya hollow of the Tyva Republic]. Vestnik KrasGAU, 2013, no. 7, pp. 146-151. (In Russ.)

4. Baryshnikova O. N., Krupochkin E.P., Mezentzeva E. M., Nepriyatel R. S., Kharlamova N.F. Kontinentalnost i okeanichnost kak faktory formirovaniya landshaftnoy struktury territorii [Continentality and oceanility as factors to form landscape structure of territory]. Izvestiya $\mathrm{Al}$ tayskogo gosudarstvennogo universiteta, 2010, no. 3-1(67), pp. 89-92. (In Russ.)

5. Bedritskiy A.I., Kurolap S.A., Vilfand R.M., Dmitrieva V.A. Strategicheskie napravleniya obespecheniya ekologicheskoy i gidrometeorologicheskoy bezopasnosti Rossii v usloviyakh sovremennykh klimaticheskikh iz-

The content is available under Creative Commons Attribution 4.0 License. 
meneniy [Strategic directions of provision of environmental and hydrometeorological safety of Russia under modern climate change conditions]. Vestnik Voronezskogo gosudarstvennogo universiteta. Seria Geografia. Geoekologia, 2019, no. 4, pp. 5-14. https://doi.org/10.17308/geo.2019.4/ 2706. (In Russ.)

6. Boychenko S.G., Voloshchuk V.M., Serdyuchenko N. N. Sovremennye prostranstvenno-vremennye variatsii indeksa kontinentalnosti i amplitudy sezonnogo khoda prizemnoy temperatury na territorii Ukrainy [Modern spacetime variations of the index of continentality and the amplitude of a seasonal course of the surface air temperature on the territory of Ukraine]. Dopovidi Natsionalnoï akademii nauk Ukraïni, 2017, no. 9, pp. 67-75. doi: https://doi.org/ 10.15407/dopovidi2017.09.067/. (In Russ.)

7. Ivanov N. N. Poyasa kontinentalnosti zemnogo shara [Continental belts of the globe]. Izvestiya Vsesoyuznogo Geograficheskogo obshchestva, 1959, v. 91, no. 5, pp. 410423. (In Russ.)

8. Isachenko A. G. Ekologicheskaya geografiya Rossii [Ecological geography of Russia]. St. Petersburg, Publ. St. Peterburgskogo universiteta, 2001. 328 p. (In Russ.)

9. Kireeva-Genenko I. A., Novikova E. P., Chumeykina A.S. Analiz i otsenka indeksa kontinentalnosti klimata v Tsentralno-Chernozemnom rayone za poslednie 30 let [Analysis and assessment of an index of continentality of climate in central black earth region over the past 30 years]. Uspekhi sovremennogo estestvoznaniya, 2017, no. 7, pp. 76-80. (In Russ.)

10. Kuznetsova E. A. Izuchenie kontinentalnosti klimata territorii Sibiri [The study of the continentality of climate in Siberia]. Sovremennye problemy geografii $i$ geologii: $k$ 100-letiyu otkrytiya estestvennogo otdeleniya v Tomskom gosudarstvennom universitete: Materialy IV Vserossiyskoy nauchno-prakticheskoy konferentsii, v. 1, Tomsk, Tomskiy gos. un-t, 2017, pp. 287-289. (In Russ.)

11. Kuznetsova E. A. Funktsii ekosistem v zone inzhenernogo osvoeniya [Ecosystem functions in the engineering development zone]. Ekologicheskoe ravnovesie: prirodnoe i istoriko-kulturnoe nasledie, ego sokhranenie i populyarizatsiya: Materialy VI mezhdunarodnoy nauchno-prakticheskoy konferentsii, St. Petersburg, Publ. Leningradskogo gosudarstvennogo universiteta im. A. S. Pushkina, 2015, pp. 133-136. (In Russ.)

12. Kuznetsova E. A., Sokolov S. N. Gidrologiya, meteorologiya i klimatologiya: klimaticheskie raschety: uchebnoe posobie [Hydrology, meteorology and climatology: climate calculations: study guide]. Nizhnevartovsk, NVGU, 2019. 86 p. (In Russ.)

13. Lapina S. N. Kharakteristika kontinentalnosti klimata Saratova i Sankt-Peterburga na fone globalnogo potepleniya [Characteristic of continental climate in Saratov and st. Petersburg during global warming]. Izvestiya Saratovskogo universiteta. Novaya seria. Seria Nauki o Zemle, 2017, v. 17, no. 4, pp. 219-221. DOI: 10.18500/ 1819-7663-2017-17-4-219-221. (In Russ.)

14. Mikhaylov V. A. Analiz kontinentalnosti klimata Krymskogo poluostrova s pomoshchyu GIS [GIS analysis of climate continentality of the Crimean peninsula]. Problemi bezperervnoï geografichnoï osviti i kartografii: Zbirnik naukovikh prats, Kharkiv, 2014, v. 19, pp. 72-76. (In Russ.)

15. Pogonysheva I. A., Kuznetsova V.P., Pogonyshev D. A., Lunyak I. I. Evropeyskie issledovaniya v ramkakh vliyaniya izmeneniya klimata na zdorove cheloveka $i$ okruzhayushchuyu sredu [European research on climate change impact on human health and environment]. Okruzhayushchaya sreda $i$ zdorove cheloveka: opyt stran Evrosoyuza: Materialy nauchno-prakticheskogo seminara, Nizhnevartovsk, Publ. "Nauka i praktika", 2018, pp. 2632. DOI: http://doi.org/10.5281/zenodo.1165006. (In Russ.)

16. Pryakhina S. I., Ormeli E. I. Raschet indeksov kontinentalnosti klimata dlya Srednego i Nizhnego Povolzhya [The calculations of the indices of continentality of climate for the Middle and Lower Volga region]. Izvestiya Saratovskogo universiteta. Novaya seria. Seria Nauki o Zemle, 2017, v. 17, no. 1, pp.17-19. DOI: 10.18500/1819-76632017-17-1-17-19. (In Russ.)

17. Sokolov S. N. Prostranstvenno-vremennaya organizatsiya proizvoditelnykh sil Aziatskoy Rossii [Spatial and temporal organization of the productive forces of Asian Russia]. Nizhnevartovsk, Publ. Nizhnevartovsk. gos. gumanit. un-ta, 2006. 317 p. (In Russ.)

18. Sokolov S.N. Sovremennoe ekonomiko-geograficheskoe polozhenie Yugry [Modern economic and geographical position of Yugra]. Geografiya i region: $M a-$ terialy Mezhdunarodnoy nauchno-prakticheskoy konferentsii, Perm, Perm. gos. nats. issl. un-t, 2015, v. III, pp. 167173. (In Russ.)

19. Sokolov S. N. Teoretiko-metodologicheskie i metodicheskie osnovy diagnostiki problem sotsialno-ekonomicheskogo razvitiya regionov Aziatskoy Rossii [Theoretical, methodological and methodical bases of diagnostics of problems of socio-economic development of regions of Asian Russia]. Novosibirsk, Publ. "Sibprint", 2013. 205 p. (In Russ.)

20. Sokolov S. N. Ekonomiko-geograficheskoe polozhenie Nizhnevartovskogo regiona [Economic and geographical position of Nizhnevartovsk region]. Vestnik Nizhnevartovskogo gosudarstvennogo universiteta, 2012, no. 1, pp. 21-31. (In Russ.)

21. Sokolov S. N., Kuznetsova E. A. Otsenka usloviy zhizni naseleniya KHMAO - Yugry po bioklimaticheskim indeksam [Assessment of living conditions of the population of the Khmao - Yugra by bioclimatic indices]. Globalnye klimaticheskie izmeneniya: regionalnye effekty, modeli, prognozy: Materialy Mezhdunarodnoy nauchno-prakticheskoy konferentsii, Voronezh, Publ. "Tsifrovaya poligrafiya”, 2019, v. 2, pp. 390-394. (In Russ.)

22. Sokolov S. N., Rzhepka E. A. Problemy i perspektivy razvitiya proizvoditelnykh sil regionov Aziatskoy Rossii [Problems and prospects of development of productive forces of regions of Asian Russia]. Priroda $i$ obshchestvo: v poiskakh garmonii, 2018, no. 4, pp. 110-120. (In Russ.)

23. Kharlamova N. F. Otsenka i prognoz sovremennykh izmeneniy klimata Altayskogo regiona [Assessment and 
forecast of current climate changes in the Altai region]. Barnaul, Publ. Altayskogo gosudarstvennogo universiteta, 2013. 156 p. (In Russ.)

24. Khromov S.P. Meteorologiya i klimatologiya: razvitie nauki, geograficheskie faktory klimata. Teplovoy rezhim atmosfery. Indeksy kontinentalnosti [Meteorology and climatology: development of science, geographical factors of climate. Thermal regime of the atmosphere. The index of continentality]. Leningrad, Publ. Gidrometeoizdat, 1978. 345 p. (In Russ.)

25. Chiglintsev V.M., Kuznetsova E. A., Colomoets V. V. Vliyanie klimatogeograficheskikh usloviy prozhivaniya naseleniya KHMAO - Yugry na zdorove molodogo pokoleniya [Climatic and geographic conditions of KhantyMansiysk autonomous area-Yugra and their effect on the health of younger population]. Mezhkulturnyy dialog $i$ sotrudnichestvo ES $i$ Rossii: opyt realizatsii proektov Zhan Monne v Nizhnevartovskom gosudarstvennom universitete: materialy mezhdunarodnoy nauchno-prakticheskoy konferentsii. Nizhnevartovsk, Nizhnevart. gos. un-t, 2019, pp.103108. (In Russ.)

26. Shver Ts. A. Atmosfernye osadki na territorii SSSR [Atmospheric precipitation on the territory of the USSR]. Leningrad, Publ. Gidrometeoizdat, 1976. 302 p. (In Russ.)

27. Baltas E. A. Climatic Conditions and Availability of Water Resources in Greece. International Journal of Water Resources Development, 2008, v. 24, no. 4, pp. 635649.

28. Charles-Edwards D. A. Physiological determination of crop growth. Sydney, Academic Press, 1984. 161 p.

29. Ciaranek D. Variability of the thermal continentality index in Central Europe. Aerul si Apa: Componente ale Mediului, v. 63. pp. 307-313.
30. Conrad V., Pollak L. W. Methods in climatology. 2nd edition. Cambridge, Harvard university press, 1950. $459 \mathrm{p}$.

31. Deniz A., Toros H., Incecik S. Spatial variations of climate indices in Turkey. International Journal of Climatology, 2011, v. 41. пою 3, pp. 394-403.

32. Filatov N., Salo Y., Nazarova L. Effect of climate variability on natural water bodies in Northwest Russia. Proc. 15th Northern Research Basins Symposium. Lulea to Kvikkjokk, Sweden, 2005, pp. 31-40.

33. Gadiwala M.S., Burke F., Alam M. T., Nawaz-ulHuda S., Azam M. Oceanity and continentality climate indices in Pakistan. Geografia-Malaysian Journal of Society and Space, 2013, v. 9, no. 4, pp. 57-66.

34. Gavilan R. G. The use of climatic parameters and indices in vegetation distribution. A case study in the Spanish System Central. International Journal of Biometeorology, 2005, no. 50, pp. 111-120.

35. Rajabi A., Shabanlou S. Index changes in future by using SDSM in Kermanshah Iran. J. Environ. Res. Develop, 2012, v. 7, no. 1, pp. 37-44.

36. Rosenberg N. J., Blad B.L., Verma S. B. Microclimate: The biological environment. 2nd edition. New York, Wiley, 1983. $495 \mathrm{p}$.

37. Sjogersten S., Wookey P.A. Decomposition of mountain birch leaf litter at the forest-tundra ecotone in the Fennoscandian Mountains in relation to climate and soil conditions. Plant and Soil, 2004, v. 262, pp. 215-227.

38. Szymanowski M., Bednarczyk P., Kryza M., Nowosad M. Spatial Interpolation of Ewert's Index of Continentality in Poland. Pure Appl. Geophys, 2017, v. 174, pp. 623-642.

Conflict of interests: The author declares no information of obvious and potential conflicts of interest related to the publication of this article.

Received: 14.01 .2020

Accepted: 20.11 .2020

Sergey N. Sokolov

Dr. Sci. (Geogr.), Professor of the Department of Geography of the Nizhnevartovsk State University, Nizhnevartovsk, Russian Federation, ORCID:

https://orcid.org/0000-0001-5639-6620, e-mail: snsokolov1@yandex.ru

Elza A. Kuznetsova

Cand. Sci. (Geogr.), Associate Professor of the Department of Geography of the Nizhnevartovsk State University, Nizhnevartovsk, Russian Federation, ORCID:

https://orcid.org/0000-0002-6248-9118, e-mail: elzanv07@yandex.ru 